Relations industrielles

Industrial Relations

\title{
Managing Intergroup Conflict in Industry, by Robert R. Blake, Herbert A. Shepard et Jane S. Mouton, Gulf Publishing Co., Houston, Texas, 1964, 210 pages.
}

\section{Jean Sexton}

\section{Volume 23, numéro 4, 1968}

URI : https://id.erudit.org/iderudit/027974ar

DOI : https://doi.org/10.7202/027974ar

Aller au sommaire du numéro

Éditeur(s)

Département des relations industrielles de l'Université Laval

ISSN

0034-379X (imprimé)

1703-8138 (numérique)

Découvrir la revue

Citer ce compte rendu

Sexton, J. (1968). Compte rendu de [Managing Intergroup Conflict in Industry, by Robert R. Blake, Herbert A. Shepard et Jane S. Mouton, Gulf Publishing Co., Houston, Texas, 1964, 210 pages.] Relations industrielles / Industrial Relations, 23(4), 706-707. https://doi.org/10.7202/027974ar

Tous droits réservés (C) Département des relations industrielles de l'Université Laval, 1968
Ce document est protégé par la loi sur le droit d'auteur. L’utilisation des services d'Érudit (y compris la reproduction) est assujettie à sa politique d'utilisation que vous pouvez consulter en ligne.

https://apropos.erudit.org/fr/usagers/politique-dutilisation/ 
chaque entreprise et par le temps moyen de travail par entreprise.

Ensuite, Kendrick complète cette étude par une analyse des changements des coûts dans l'industrie autres que ceux de la maind'oeuvre (taxes, prix du capital, productivité du capital, etc.). Enfin, Egbert fait une analyse du partage des profits par les différents facteurs de l'industrie, et des changements survenus dans ce partage ou cours des années.

Troisième partie: "Basic Industry Product Estimates ». Les études de cette partie sont consacrées surtout à la discussion et à l'utilisation des estimés de base. Gottsegen et Ziemer décrivent le concept basique et les méthodes utilisées pour évaluer le produit brut par industrie. Gehman et Motheral décrivent I'indexe numérique (Federal Reserve Bulletin) de production selon des regroupements particuliers de marché (biens de consommation, équipement et matériel). Enfin, Gartson et Worton exposent les difficultés $d^{\prime}$ isoler des mesures de la production domestique (industrie canadienne) et décrivent les progrès en ce sens par la table des nouvecux estimés.

Signalons finalement le grand nombre de tableaux et d'histogrammes qui illustrent bien la richesse des données statistiques et leurs multiples utilisations.

\section{René PARENTEAU}

\section{Employee Compensation under the Income}

Tax, by C. Harry Kahn, National Bureau of Economic Research Inc., New York, 1968,142 pp.

The object of this study is to examine the impact of the personal income tax on employee compensation, the latter's importance as a source of tax revenue, and the reasons for the striking changes which have taken place over the last two decades in the share of income tax revenue attributable to employees compensation.

This study is organized around four major topics. First, as a prelude to discussing its share in personal income tax revenue, the author examines the relative coverage of wage and salary income on tax returns and its effects on the share of total income reported. In second place, the size distribution and composition of income reported on returns with wages and salaries are investigated. This was done to identify relevant income characteristics of the tox- payers who are the recipients of wages and salaries. Third, the effects of and reasons for the major statutory provisions which have at one time or another been aimed at the tax treatment of employee compensation are discussed. Finally, the author presents estimates of the tax liability attribuable to wages and salaries for a period of thirty-five years and analyse their share in total tox liability in the light of the informotion in earlier chapters.

The study, which covers the 35 years period from 1939 to 1964, shows how wages and salaries differ from other income sources in their coverage on tox returns, in their distribution by income size groups, and in the legal provisions affecting their inclusion in the statutory concept of income. Attention is also given to special problems in the taxation of wages and salaries, such as taxes on the income of working wives, earned, versus unearned income, excludable sick pay, and deferred compensation.

This report is the tenth in the Nationo Bureau's series of fiscal studies.

\section{Pierre DIONNE}

\section{Managing Intergroup Conflict in Industry,} by Robert R. Blake, Herbert A. Shepard et Jane S. Mouton, Gulf Publishing Co., Houston, Texas, 1964, 210 pages.

Tous ceux qui occupent un poste de direction quelconque formulent habituellement les deux mêmes critiques envers les sciences du comportement: en plus de reconnaître que les connaissances dans ce comaine sont éparpillées dans une foule de volumes de nature différente, les cadres reprochent oux théoriciens de ne pas se pencher suffisamment sur leurs préoccupations pratiques et quotidiennes. II n'est alors pas surprenant de constater les grandes difficultés d'appli. cation des conclusions prônées par les théoriciens des sciences du comportement.

Pour tenter de résoudre ce problème d'adaptation de la théorie au monde pratique, les auteurs ont écrit ce livre spécialement pour les « managers $»$.

Pour ce faire, Blake, Shepard et Mouton

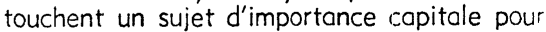
les dirigeants. Ils proposent comment atteindre une coordination efficace entre les diverses parties d'une organisation telles que la direction et le syndicat, les ventes et lo production. la ligne hiérarchique et les fonctions conseils, enfin entre le siège social et les filiales. 
Dans ce livre, les auteurs du Managerial Grid voient dans le conflit trois dimensions de base: la première « The Win-Lose Orientation to Intergroup Disagreement * suppose pour que l'un gagne que l'autre perde. En second lieu, les auteurs examinent la solution d'un règlement de conflit par une tierce personne, pour finalement en arriver à l'approche de la recherche de la solution en groupe.

Ce n'est donc pas un livre de théorie et de principes non vérifiés. Cependant, il ne fout pas le considérer comme un livre de recettes répondant à tous les problèmes de conflit entre les différents groupes d'une organisation.

Ce conflit, il est inévitable. II peut cependant être atténué dans une certaine mesure por l'application des sciences du comportement.

\section{Jean SEXTON}

White-and-Blue-Collors in a Mill Shutdown, by Felician F. Foltman, New York State School of Industrial and Labor Relations, Cornell University 1968, 132 pages.

La fermeture d'une usine ou la réduction des opérations mènent infailliblement au renvoi des plusieurs centaines de travailleurs. Le phénomène se présente de plus en plus fréquemment dans notre économie rapidement changeante; il est la source de situations tragiques pour les travailleurs concernés et soulève d'importants problèmes connus par toutes nos politiques de maind'oeuvre.

M. Foltman a entrepris l'étude d'un cas courant, mais il en fait une analyse qui peut servir dans la moyenne générale des cas. Son optique est profondément humaine car c'est en termes d'attitudes ouvrières qu'il analyse le problème: attitudes face à lo fermeture de l'usine, attitudes face au renvoi, à la mobilité exigée par ce renvoi, à la recherche d'un nouvel emploi. En plus de nous donner cette approche particulière du problème, $M$. Foltman nous fournit un modèle d'analyse.

$\mathrm{Ce}$ modèle d'analyse se retrouve essentiellement dans le questionnaire qu'il a utilisé pour son étude, dans l'approche globale du problème (sources et conséquences proches et éloignées), dans la description de variables propres et dans les relations (corrélations) qu'il a tenté d'établir entre ces variables pour dégager les conclusions généroles. Ainsi, por exemple, il étudie les relations entre l'âge, la formation et la mobilité des travailleurs; les relations entre le statut familial, la vie sociale, et la mobilité.

Si les résultats de l'analyse ne nous indiquent pas des solutions certaines à ce genre de problèmes, ils nous indiquent des voies universelles de recherche qui mèneront certainement à des solutions particulières parfaitement adaptées à des conditions particulières.

\section{L.-René PARENTEAU}

\section{Personnel: The Human Problems of Manage-} ments, Second Edition, by George Strauss and Leonard R. Sayles, Prentice-Hall Inc., New Jersey, 1967, 756 pages.

Par ce «textbook», les outeurs veulent couvrir le spectre complet des questions qui concernent la direction du personnel et les relations humaines.

Le livre indique clairement et de foçon analytique de quelle façon on peut développer des procédures et des politiques appropriées pour en arriver à l'utilisation optimale des ressources humaines. II offre le bagage théorique fondamental des sciences du comportement, y intègre les résultats de la recherche sur les relations humaines, et y ajoute les procédures modernes utilisées dans I'administration des ressources humaines. Le tout est assorti d'études de cas et de problèmes qui veulent initier le lecteur à l'utilisation éventuelle de ces techniques.

Le but des auteurs est de suggérer une approche systématique et unifiée aux problèmes de personnel auxquels font face les organisations industrielles. Les réponses qu'ils fournissent ne sont pas de simples « recettes » (do this or do that). Ils soulignent que dans plusieurs cas, il est très difficile sinon impossible, de même suggérer des réponses. II s'agit plutôt de saisir les a bonnes questions », de bien poser les problèmes.

Cette imposante publication comprend sept (7) parties. On y traite successivement des résultats ou des contributions de diverses spécialités à la compréhension et au règlement des problèmes humains dans l'entreprise.

Les parties I, II et III traitent principalement des fondements psychologiques et sociologiques de la vie à l'intérieur d'une entreprise et à l'intérieur du monde industriel. Partant de l'individu, de ses besoins, de ses aspirations et de son comportement à l'intérieur d'un groupe, on traite successivement 